\title{
Improve the surface hardness of the blend PMMA / n- MgTiO3 to resist caries and bacteria
}

\author{
Hawraa Hussain Al-esami1', Zainab AL-Ramadhan¹, Ziyad Shihab Ahmed AL-Sarraj², Fadhil K. Farhan³
}

\begin{abstract}
In this study, the MgTiO3 ceramic system was used in a dry mixing method with 2: 1 mol and was reinforced to white acrylic powder used in dental applications to form a mixture of $1 \%, 2 \%, 3 \%, 4 \%$ and $5 \%$ of ceramic powder. The ultrasound technique was used to disperse the powder and distribute it homogeneously in the chloroform solution for one hour and then mixed it with acrylic powder in the same technique for half an hour. The tests were done for the samples made using industrial saliva with bacteria. Calculate the rate of wear using Pin on disc method. The results were interpreted based on the resulting images from the scanning electron microscope and the density of the prepared samples.
\end{abstract}

Keywords: bioceramic, $\mathrm{MgTiO}_{3}$, dry mix, caries rate, wear rate

\section{INTRODUCTION}

Heat-curing acrylic resins are frequently used in temporary prosthetic-base materials, provisional prosthesis, and orthodontic removable appliances such as retainers and functional appliances [1,2]. Polymethylmethacrylate (PMMA) is generally used as a common component of acrylic materials due to its optical properties, biocompatibility and aesthetics [3]. However, low mechanical properties against impact, bending, and fatigue are important issues to be addressed in order to improve acrylic polymers properties for removable acrylic appliances and dentures [4]. The acrylic resin materials are typically low in strength, soft and fairly flexible, as well as brittle on impact, and fairly resistant to fatigue. The additives could affect the toughness, microstructure and deformation behavior under the impact and flexural tests $[5,6]$. As the fracture resistance of a denture base resin is important, many approaches have been used to strengthen acrylic resin dentures. These approaches involve the use of metal wires or plates, fibers, metal powder or rubber toughening agents. These reinforcing methods were done to improve the mechanical properties of the denture base resins and to overcome the problem of denture fractures $[7,8]$. Currently, dental composites consist of two phases: the synthetic polymer matrix and inorganic fillers. They are linked together via a coupling agent (such as silane). In addition, initiators and activators are added inorganic fillers such as quartz, colloidal silica, and silica glass containing small amounts of zirconium, strontium and barium are the most commonly used fillers. The inorganic fillers play an important role in improving the strength and elastic stiffness [9]. On the other hand, they reduce water absorption, polymerization shrinkage and coefficient of thermal expansion. Bonding of organic and inorganic phases by coating the fillers with a coupling agent results in the formation of a strong covalent bond. This is a key factor in terms of good mechanical properties of dental composite. Coupling agents have two functional groups in order to link the matrix and the fillers chemically [10]. Composites with nanofillers are so called nanocomposites [11]. Different nanofillers have been introduced to dental composites. However, in this thesis, we are introducing a novel flowable nanocomposites reinforced with $\mathrm{TiO}_{2}$ nanotubes. Nanofillers do not scatter visible light as they shrink to a fraction of this light wavelength $(0.4-0.8 \mu \mathrm{m})$. So, they are invisible and they can improve the optical properties of composites [12]. Kim et al. [13] produced a new bioactive bone cement that consists of HA, PMMA. It was indicated that compressive strength of the cement was lower than the pure PMMA. Mechanical properties of acrylic base cements reinforced with HA have been studied by Serbetci et al. [14]. It

\footnotetext{
1 Al-Mustansiriyah University College of Education, Bagdad - Iraq

2 Ministry of Science and Technology, Bagdad - Iraq

3 Karkh University of Science Faculty of Science, Medical physics, Bagdad - Iraq
}

Correspondence: Hawraa Hussain Al-esami

Al-Mustansiriyah University College of Education, Bagdad - Iraq

E-mail: hussainalesamihawraa@gmail.com

Received: 17 Mar 2018, Accepted: 1 Jul 2018

(C) 2018 by the authors; licensee Modestum Ltd., UK. This article is an open access article distributed under the terms and conditions of the Creative Commons Attribution License (http://creativecommons.org/licenses/by/4.0/).

Electronic Journal of General Medicine 


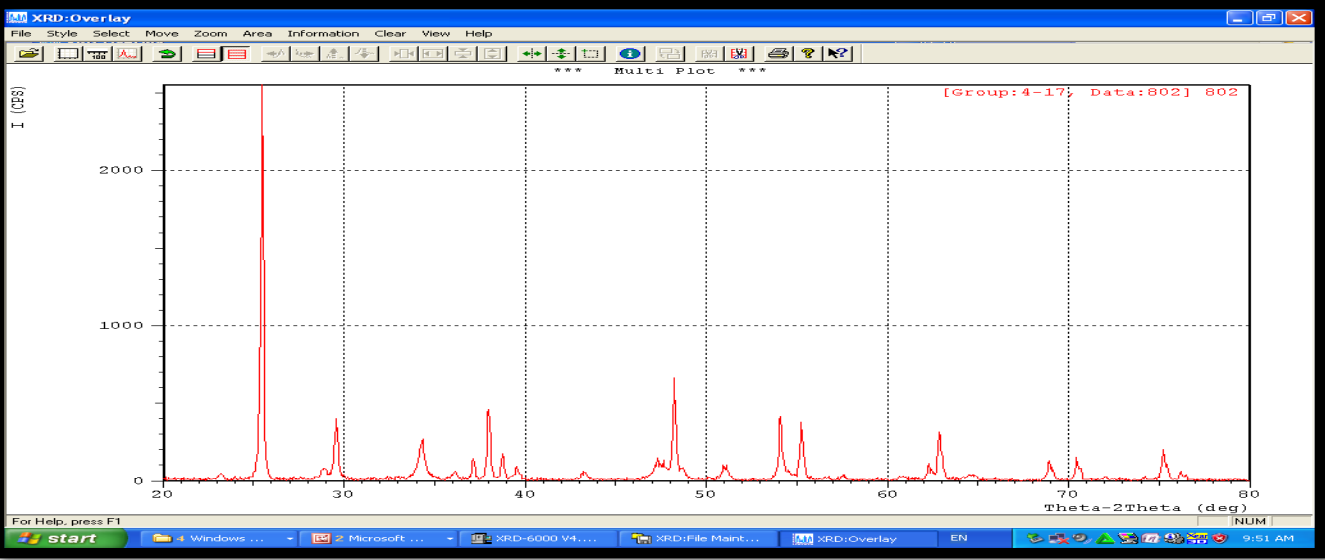

Figure 1: X-Ray test of bio - ceramic powder $\left(\mathrm{MgTiO}_{3}\right)$

Table 1: Experimental and surface hardness values

\begin{tabular}{|c|c|c|}
\hline NO. Samples & Density $\left(\mathrm{Kg} / \mathrm{m}^{3}\right)$ & Hardens (MPa) \\
\hline PMMA & 1150 & 19.5 \\
\hline PMMA-1\%(MgTiO 3$)$ & 1263 & 23.2 \\
\hline PMMA-2\%(MgTiO 3$)$ & 1355 & 23.9 \\
\hline PMMA-3\%(MgTiO 3$)$ & 1441 & 32.7 \\
\hline $\mathrm{PMMA}-4 \%\left(\mathrm{MgTiO}_{3}\right)$ & 1532 & 54.8 \\
\hline PMMA-5\%(MgTiO 3$)$ & 1612 & 65.2 \\
\hline
\end{tabular}

was found that addition of HA caused to increase both compressive strength and fatigue life unlike tensile strength of the cement. Wang et al. [15] and Roeder et al. [16] studied the effects of particle size and shape, and found that smaller particle size and larger aspect ratio increased the com posite mechanical properties. Because there are few papers that study about addition of nano hydroxyapatite in PMMA, this study tries to fill this gap. In this research, mechanical properties of nano HA-reinforced PMMA cement were investigated by using three point bending, compressive and wear test.

\section{EXPERIMENTAL AND MATERIALS USED}

The bio-ceramic powder was prepared from the blend of magnesium oxide $(\mathrm{MgO})$ with titanium oxide $\left(\mathrm{TiO}_{2}\right)$ with $(2: 1)$ $\mathrm{mol}$ and particale size of $42 \mathrm{~nm}$. The grinding balls were used for the preparation of the ceramic powder with acetone solvent for 3 hours until we obtained a homogeneous powder. The reaction was then done at $1250^{\circ} \mathrm{C}$ using a tubular furnace at $10^{\circ} \mathrm{C}$ per minute for 2 hours until the reaction was completed to obtain a bio-ceramic powder $\left(\mathrm{MgTiO}_{3}\right)$ consisting of $34 \%$ Magnesium oxide and $66 \%$ titanium oxide in the nanometer Figure 1 show X- Ray test of $\left(\mathrm{MgTiO}_{3}\right)$. The ceramic powder was then mixed in different $(1 \%, 2 \%, 3 \%, 4 \%$ and $5 \%)$ by weight proportions with white acrylic powder PMMA with the chlorophromic solvent using an ultrasound device to obtain the Nanocomposies which was formed with a $20 \mathrm{~mm}$ and $3 \mathrm{~mm}$ Teflon mold for the laboratory tests of antibacterial and caries. The wear rate tested by pin - on- disc method was used $10 \mathrm{~mm}$ diameter and $30 \mathrm{~mm}$ thickness Teflon mold.

\section{RESULT AND DISCUSSION}

\section{Surface Hardness and Density}

A considerable enhancement of hardness is observed by the nano composites in comparison to pure sample see Table 1 and Figure 2. It was observed an increase in the hardness curve by increasing the concentration of the bioceramic powder $\left(\mathrm{MgTiO}_{3}\right)$ Improvement of hardness with the increase in concentration of bio-ceramic powder $\left(\mathrm{MgTiO}_{3}\right)$ nanofillers may have be due to inherent characteristics of the $\left(\mathrm{MgTio}_{3}\right)$ particles. ( $\left.\mathrm{MgTiO}_{3}\right)$ possesses strong ionic interatomic bonding. The results of this study are in good agreement with the findings reported by others who concluded that reinforcement of ceramics $[17,18]$. 


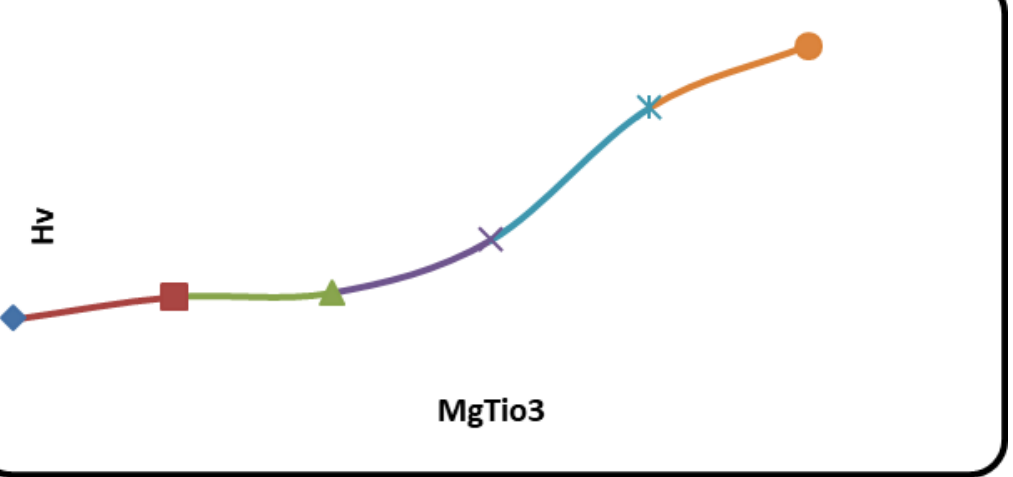

Figure 2: Vickers hardness Values of Pure and Nanocomposites

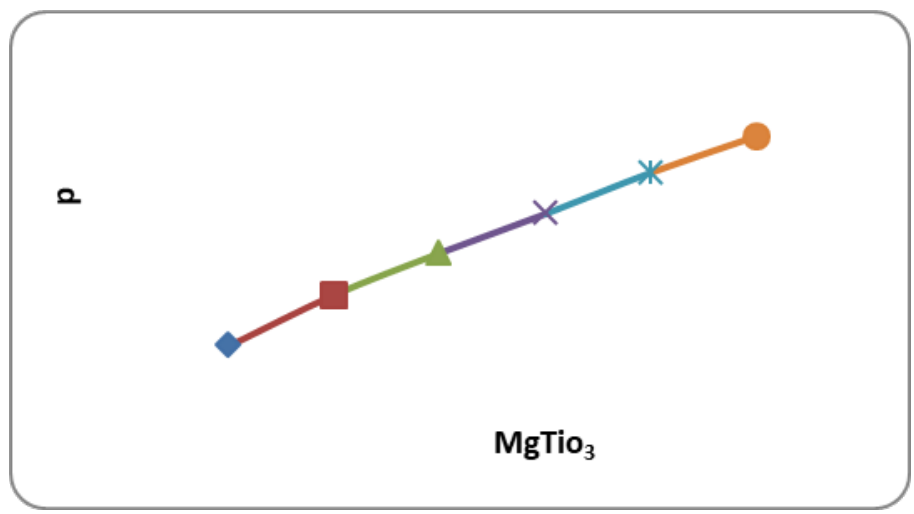

Figure 3: Density values of pure and nanocomposites

Table 2: Antibacterial activity of (PMMA-MgTio 3 ) nanocomposite

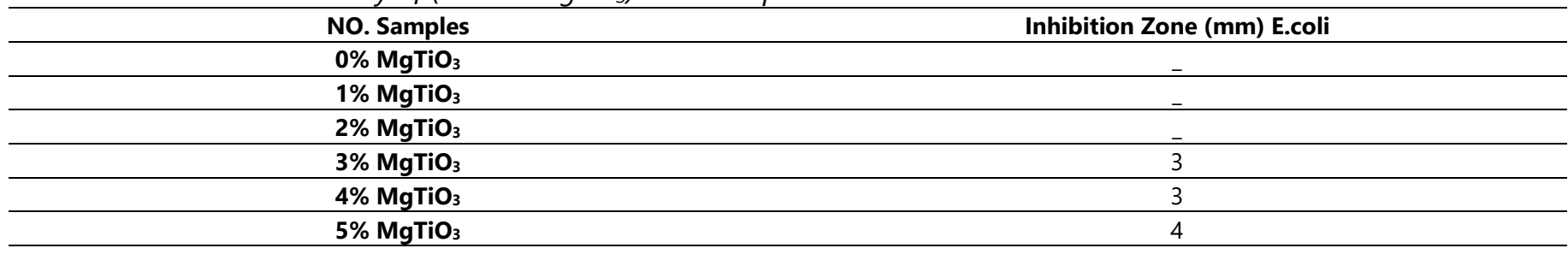

Figure 3 shows the relationship between density and Nano - (MgTio $)$ where it shows that the density increases with increasing concentration $\left(\mathrm{MgTio}_{3}\right)$. The $\left(\mathrm{MgTio}_{3}\right)$ nanoparticles when added to polymer tended to create a linkage of bonding between nanoparticles and polymer which sometime results in higher density of the nanocomposites and this a good agreement with $[19,20]$,

\section{Antibacterial and Caries rate Antibacterial measurements}

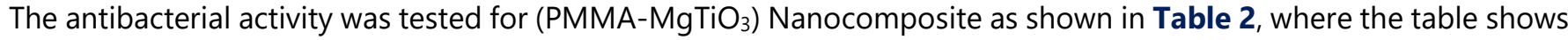
no inhibition activity recorded for $(0 \%, 1 \%, 2 \%)$ inhibition activity, while inhibition activity for $(3 \%, 4 \%, 5 \%)$ increases with the increase of the weight percentages of $\mathrm{MgTiO}_{3}$ nanoparticles, demonstrated that nano-MgTio3 exhibited high activity against bacteria due to the interaction of particles and bacteria this is agreement with [21]. The antibacterial properties are related to the total surface are of the nanoparticles, smaller particles with larger surface to volume ratios have great antibacterial activity [76,77]. Figure 4 showed antibacterial activity of (PMMA-MgTio $)$ nanocomposite. 


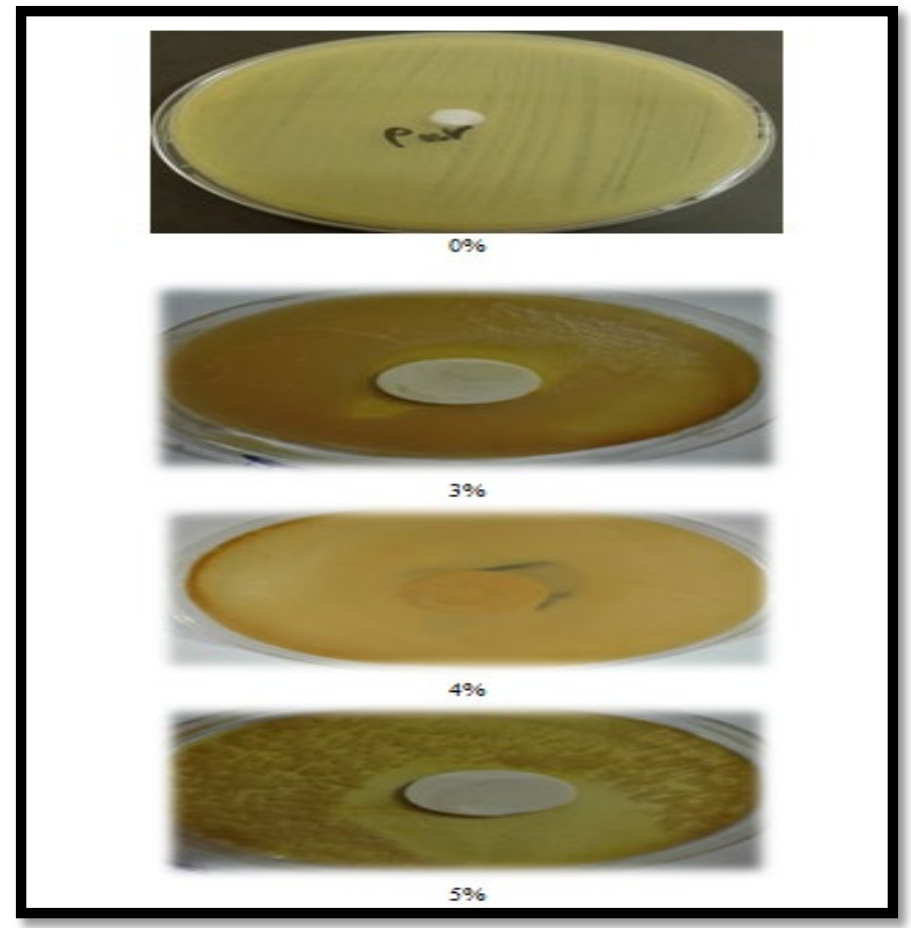

Figure 4: Antibacterial activity of (PMMA-MgTio $)$ nanocomposite

Table 3: The value of wear measurements

\begin{tabular}{|c|c|c|c|c|}
\hline NO. Samples & $\Delta \mathbf{w}$ & $W r \times 10^{\wedge}-6$ & $W v \times 10^{\wedge}-6$ & $\mathbf{W}_{\text {coeff. }}$ \\
\hline $0 \% \mathrm{MgTiO}_{3}$ & 0.14 & 0.38 & 14.1 & 0.03 \\
\hline $1 \% \mathrm{MgTiO}_{3}$ & 0.0073 & 0.018 & 6.73 & 0.0022 \\
\hline $2 \% \mathrm{MgTiO}_{3}$ & 0.0033 & 0.0075 & 0.38 & 0.0089 \\
\hline $3 \% \mathrm{MgTiO}_{3}$ & 0.0013 & 0.0041 & 0.22 & 0.0051 \\
\hline $4 \% \mathrm{MgTiO}_{3}$ & 0.0011 & 0.0009 & 0.13 & 0.0039 \\
\hline $5 \% \mathrm{MgTiO}_{3}$ & 0.0004 & 0.00081 & 0.09 & 0.0009 \\
\hline
\end{tabular}

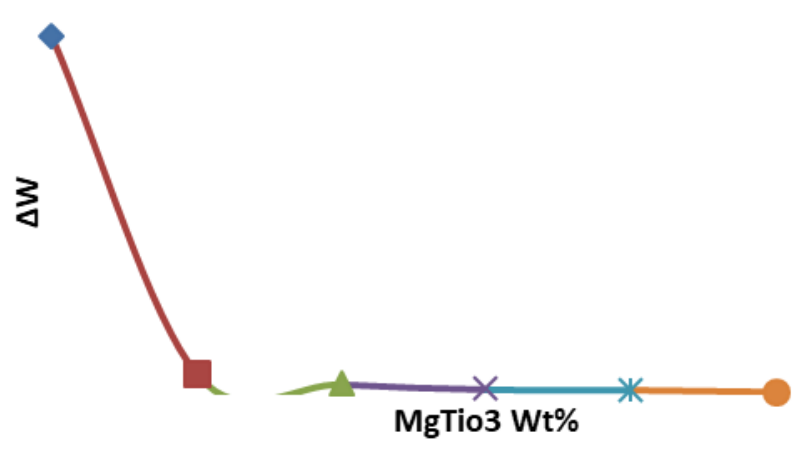

Figure 5: Wear weight values of Neat and Nanocomposites

\section{Caries rate (wear measurements)}

The rate of decay is the measurement of wear and tear, where the wear tests are shown in the table Figures 5-7 shows the wear properties are studied for $(0 \%, 1 \%, 2 \%, 3 \%, 4 \%$ and $5 \%)$ bio-ceramic powder and reported in Table 3, it is observed that, the $(\triangle \mathrm{W}, \mathrm{Wr}, \mathrm{Wv})$ It can be observed that wear rate decreases by increasing in $\left(\mathrm{MgTio}_{3}\right)$ content. This is because of presence of ceramic powders which have high hardness that can improve sliding wear rate $[67,68]$, and due to the fact that blend resin can easily remove at sliding surfaces (contact area) but in the nanocomposite case the ceramic $\mathrm{Nano}-\left(\mathrm{mgTiO}_{3}\right)$ particles act as a rough surface relative to the counter face against which they slide. For neat blend is a good in agreement with [68]. 


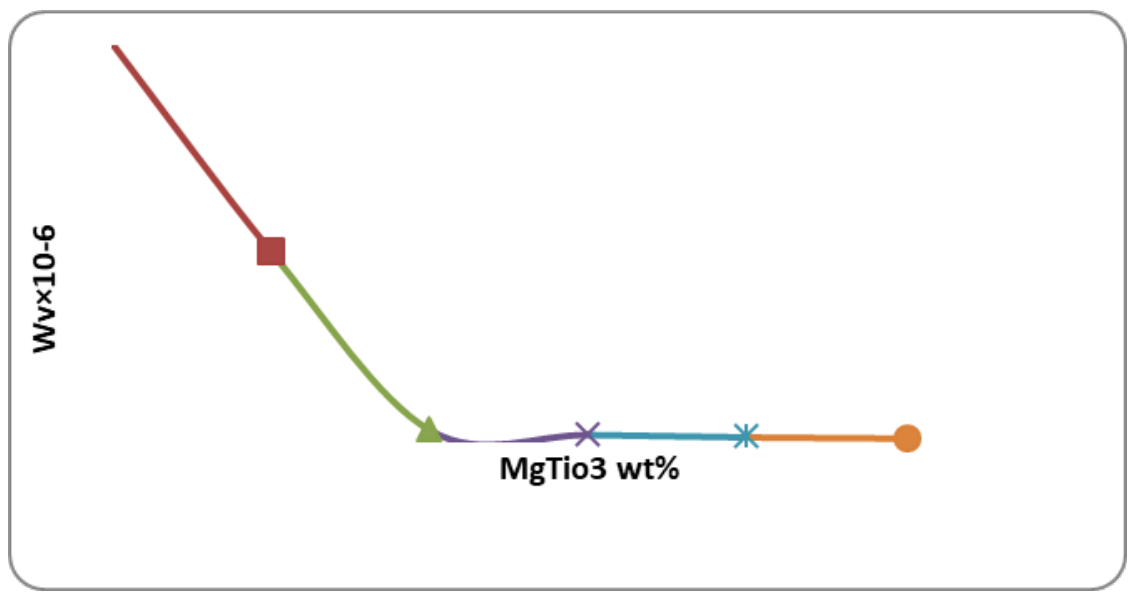

Figure 6: The wear volume values of Neat and Nanocomposites

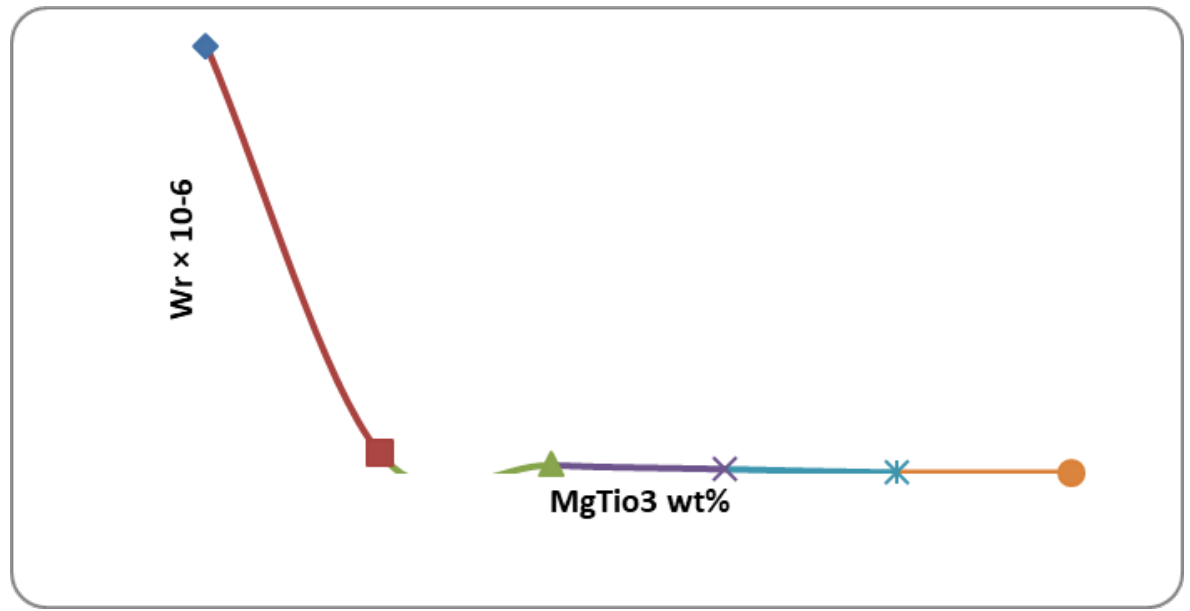

Figure 7: Wear rate values of Neat and Nanocomposites

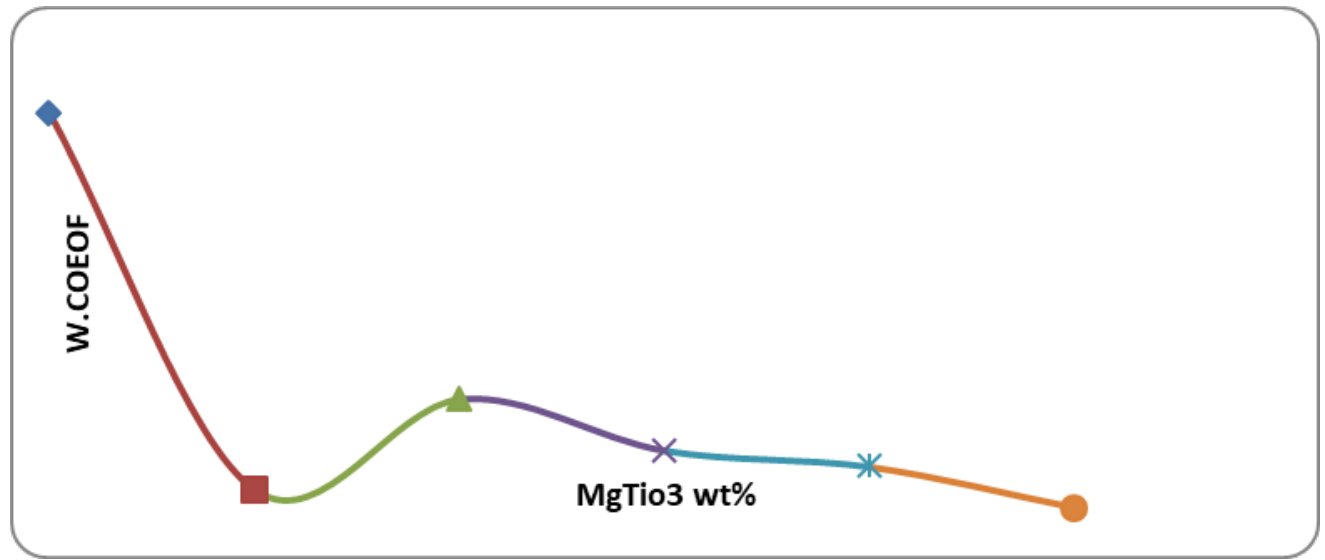

Figure 8: Wear coefficient values of Neat and Nanocomposites

Figure 8 shows results wear coefficient where their behavior depends on behavior of wear volum.

We observe from the above results that wear and tear tests that represent decay rate have improved after adding bio-ceramic powder best anti-wear ability was obtained when nanocomposite contained $5 \%$ Nano - (mgTio $)$.

\section{REFERENCES}

1. Price CA. A history of dental polymers. J Prosthodont. 1994;8:47-54.

2. Soh MS, Sellinger A, Yap AU. J Dental Nanocomposites. Curr Nanosci. 2006;24:373-81. 
3. Kanie T, Arikawa H, Fujii K, Inoue K. Physical and mechanical properties of PMMA resins containing gamma methacryloxypropyltrimethoxy-silane. J Oral Rehabil. 2004;31:166-71. https://doi.org/10.1111/j.13652842.2004.01043.x PMid:15009602

4. Vallo $\mathrm{Cl}$, Abraham GA, Cuadrado TR, San Román J. Influence of cross-linked PMMA beads on the mechanical behavior of self-curing acrylic cements. J Biomed Mater Res B Appl. Biomater. 2004;70:407-16. https://doi.org/10.1002/jbm.b.30054 PMid:15264326

5. Mowade TK, Dange SP, Thakre MB, Kamble VD. Effect of fiber reinforcement on impact strength of heat polymerized polymethyl methacrylate denture base resin: in vitro study and SEM analysis. Journal of Advanced Prosthodontics. 2012;4:30-36. https://doi.org/10.4047/jap.2012.4.1.30 PMid:22439098 PMCid:PMC3303918

6. Faot H, Panza LHV, Garcia RCM, Bel Curry AAD. Impact and Flexural Strength, and Fracture Morphology of Acrylic Resins with Impact Modifiers. Open Dentistry Journal. 2009;3:137-143. https://doi.org/10.2174/1874210600903010137 PMid:19657461 PMCid:PMC2720515

7. Narva KK, Lassila LV, Vallittu PK. The static strength and modulus of fiber reinforced denture base polymer. Dental Materials. 2005;21:421-428. https://doi.org/10.1016/j.dental.2004.07.007 PMid:15826698

8. Bashi TK, Al-Nema LM. Evaluation of Some Mechanical Properties of Reinforced Acrylic Resin Denture Base Material (An In Vitro Study). Al-Rafidain Dental Journal. 2009;9:57-65.

9. Chen $\mathrm{M}-\mathrm{H}$. Critical reviews in oral biology \& medicine: Update on dental nanocomposites. J Dent Res. 2010;89(6):549-60. https://doi.org/10.1177/0022034510363765

10. Ferracane JL. Current trends in dental composites. Crit Rev Oral Biol Med. 1995;6(4):302-18. https://doi.org/10.1177/10454411950060040301 PMid:8664421

11. Lindberg A. Resin composites: Sandwich restorations and curing techniques Umeå Odontologi;2005.

12. Mitra SB, Wu D, Holmes BN. An application of nanotechnology in advanced dental materials. The J of the Am Dent Ass. 2003;134(10):1382-90. https://doi.org/10.14219/jada.archive.2003.0054

13. Bong KS, Jick KY, Lim YT, Su AP. The Characteristics of a Hydroxyapatite-Chitosan-PMMA Bone Cement. Biomaterials. 2004;25(26):5715-23. https://doi.org/10.1016/j.biomaterials.2004.01.022 PMid:15147817

14. Serbetci K, Korkusuz F, Hasirci N. Thermal and Mechanical Properties of Hydroxyapatite Impregnated Acrylic Bone Cements. Polymer Testing. 2004;23(2):145-55. https://doi.org/10.1016/S0142-9418(03)00073-4

15. Wang M, Joseph R, Bonfield W. Hydroxyapatite- polyethylene Composites for Bone Substitution: Effects of Ceramic Particle Size and Morphology. Biomaterials. 1998;19(24):2357-66. https://doi.org/10.1016/S01429612(98)00154-9

16. Roeder RK, Sproul MM, Turner CH. Hdroxyapatite Whiskers Provide Improved Mechanical Properties in Reinforced Polymer Composites. Journal of Biomedical Materials Research Part A. 2003;67A(3):801-12. https://doi.org/10.1002/jbm.a.10140 PMid:14613228

17. Guo QB, Rong MZ, Jia GL, Lau KT, Zhang MQ. Sliding Wear Performance of Nano-SiO2/Short Carbon Fiber/Epoxy Hybrid Composites. Wear. 2009;266(7-8):658-65. https://doi.org/10.1016/j.wear.2008.08.005

18. Eriksson M, Jacobson S. Tribological surfaces of organic brake pads. Tribology Int. 2000;33(12):817-27. https://doi.org/10.1016/S0301-679X(00)00127-4

19. Eriksson M, Jacobson S. Tribological surfaces of organic brake pads. Tribology Int. 2000;33(12):817-27. https://doi.org/10.1016/S0301-679X(00)00127-4

20. Vojdani $M$, Bagheri $R$, Khaledi AAR. Effects of Aluminum Oxide Addition on the Flexural Strength, Surface Hardness, and Roughness of Heat-Polymerized Acrylic Resin. Journal of Dental Sciences. 2012;7:238-44. https://doi.org/10.1016/j.jds.2012.05.008

21. Aydin Sevinç B, Hanley L. Antibacterial activity of dental composites containing zinc oxide nanoparticles. Journal of Biomaterials. 2010;94B(1):22-31. https://doi.org/10.1002/jbm.b.31620

22. Cho K-H, Park J-E, Osaka T, Park S-G. The study of antimicrobial activity and preservative effects of nanosilver ingredient. Electochim acta. 2005;51(5):956-60. https://doi.org/10.1016/j.electacta.2005.04.071

23. Martínez-Castañón GA, Niño-Martínez N, Martínez-Gutierrez F, Martínez-Mendoza JR, Ruiz F. Synthesis and antibacterial activity of silver nanoparticles with different sizes. J Nanoparticle Res. 2008;10(8):1343-48. https://doi.org/10.1007/s11051-008-9428-6 